\title{
A Simple Robust Active BMS for Lithium Ion Battery Stacks.
}

\author{
Thomas Conway
}

\begin{abstract}
A simple active battery management system for lithium ion battery stacks is described, that is robust and scalable. The architecture is based on an isolation unit consisting of a small equal turns ratio high isolation transformer with two diodes. One isolation unit is connected to each series connected cell in the battery stack and enables both accurate cell voltage monitoring and active cell balancing.

The output of the isolation unit is completely galvanically isolated and thus suitable for high voltage packs with stringent safely requirements such as automotive and industrial electrical vehicles.

Detailed measurements results are presented and a complete prototype for a $\mathrm{LiFePO4} 16 \mathrm{~s} 2 \mathrm{p} 2 \mathrm{kWh}$ battery module is constructed and its performance measured.
\end{abstract}

Index Terms-Battery Management System, Cell Balancing, Cell Isolation, Flyback Transformer, Lithium Ion Battery Stacks.

\section{INTRODUCTION}

Battery management systems (BMSs) for Lithium Ion Batteries (LIBs) are a key enabler for their application in a wide variety of products including electric vehicles[1]. For large battery packs in applications such as electric vehicles, two critical functions of the BMS system are 1: individual cell voltage monitoring and 2: individual cell energy balancing. High voltage packs require a large number of cells (typically in the 100's) to be connected in series to achieve the required voltage level. Such a pack thus needs a large number of components in the BMS to monitor and balance each cell individually. Large numbers of components and their required interconnect can potentially result in reduced reliability. This work focuses on the requirement for simplicity and robustness as the key drivers in the BMS design.

A wide variety of battery management architectures have been reported in the literature [2],[3]. A main distinction has been made between passive systems which balance cells by removing energy from them and dissipating it as heat and active systems which can add energy to a cell, taking it from other cells[4][5], modules[6], the full pack or external sources[7].

The fly-back architecture[8] provides a very convenient method for individual battery balancing as it inherently provides an isolated DC voltage to DC current conversion that can be individually controlled for each cell. However, accurate cell voltage monitoring with the fly-back structure is potentially less accurate than the transformer technique of [9]. In this

Thomas Conway is a lecturer in the ECE dept. of the University of Limerick, Limerick, Ireland

Contact: Dr. Thomas Conway Lecturer, ECE Dept University of Limerick National Technology Park Limerick, Ireland. Tel +353 61 202628, Email thomas.conway@ul.ie paper, a proposed method of accurate cell voltage monitoring within the fly-back structure is developed. The architecture in this paper achieves the dual functions of battery balancing and accurate cell voltage monitoring using a single transformer isolation unit per cell.

This paper is structured with a description of the proposed architecture in section II with the key development of accurate voltage measurement being developed in section II-A. The active cell balancing is described in section II-B. Prototype construction and measurements are presented in section III for both the individual cell interface units in section III-A and a full 16p2s LiFePO4 $2 \mathrm{kWh}$ battery module in section III-B. A detailed comparison table with other architectures from the literature is shown in section IV.

\section{Proposed Architecture}

Fig. 1 shows the cell interface unit based on a small transformer to be used in a fly-back configuration. The lithium ion cell is connected to the cell port and the diode $\mathrm{D} 1$ is reverse biased ensuring that no current is ever drawn from the cell through the unit.

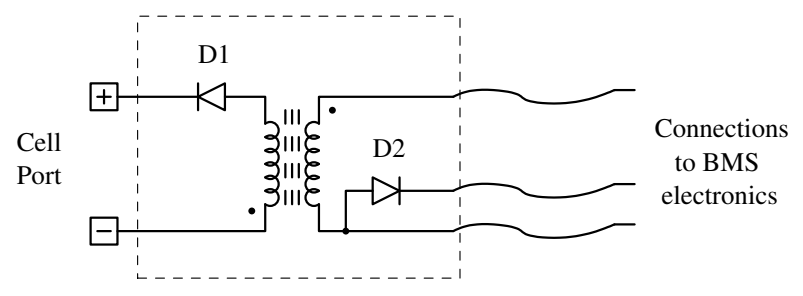

Fig. 1. Cell Interface Unit.

Balancing is achieved by adding energy to the cell. While the diode forward drop reduces the efficiency of the transfer, the emphasis in this design is on robustness. A Schottky diode could be used if efficiency is of higher priority, but at the expense of increased reverse biased leakage particularly at higher temperatures. Many designs[8] use MOSFET switches to increase the efficiency of the transfer, but this is avoided here to limit the number of isolation boundaries in the design and prevent any possibility of external signals shorting the cell, either by error or through fault conditions.

The key requirement for any BMS system is accurate voltage monitoring of the cell voltage and for this reason a matching diode $\mathrm{D} 2$, in close thermal contact with the diode D1 is included in the cell interface unit. This addition diode allows for the voltage drop of the diode D1 to be compensated for when operated in the measurement mode, on the basis that 
the cell interface unit has both diodes at the same temperature. Voltage drop matching also requires that both diode carry the same current and this is arranged as described in section II-A.

Fig. 2 shows the proposed architecture for the BMS utilizing multiple cell interface units. A common supply line and a voltage sense line is connected to each unit with a separate drive wire to select which one to activate. Voltage monitoring is done in a serial manner, selecting one unit at a time, but any number of cell balancing operations can be complete in parallel. A sense resistor Rs is used to measure the current in the transformer primaries during voltage monitoring operation, but can be bypassed when multiple transformers are activated during balancing.

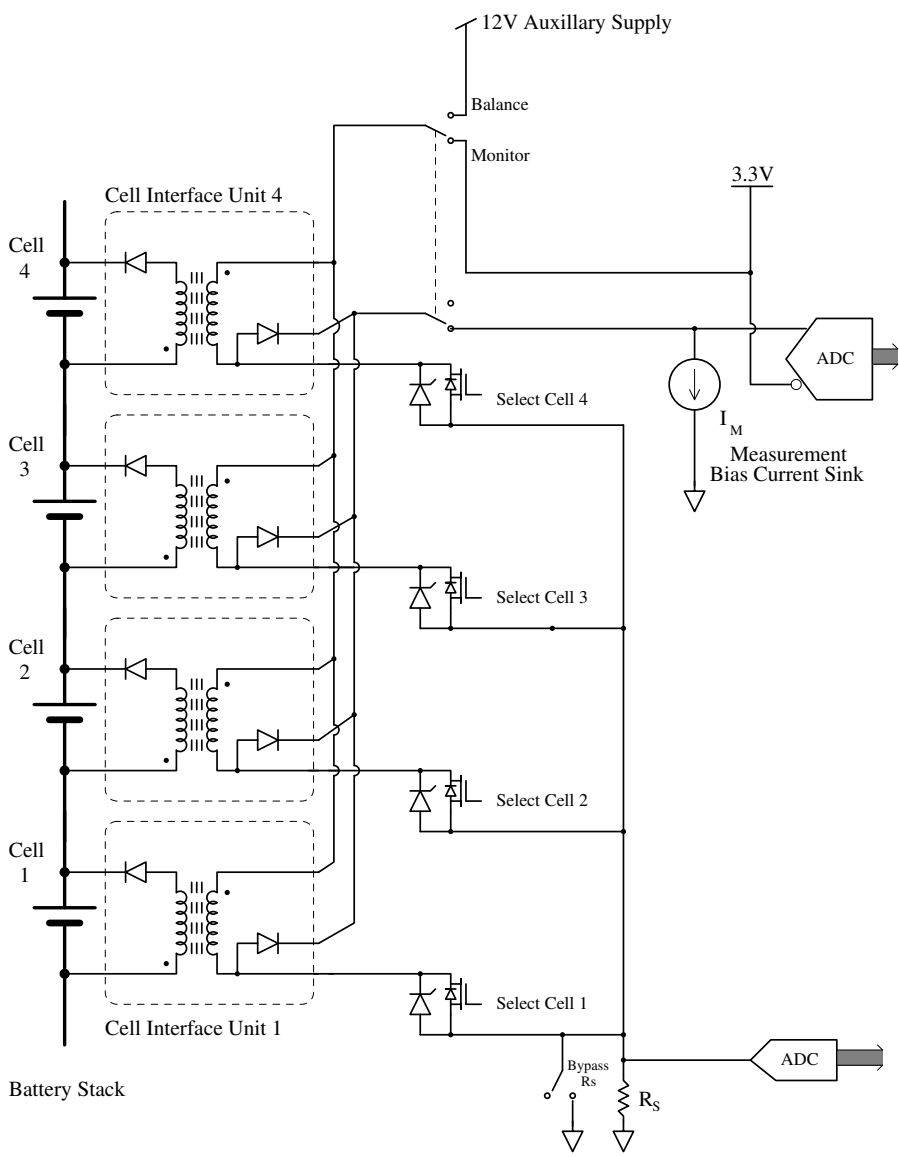

Fig. 2. Proposed BMS architecture.

\section{A. Cell Voltage Monitoring}

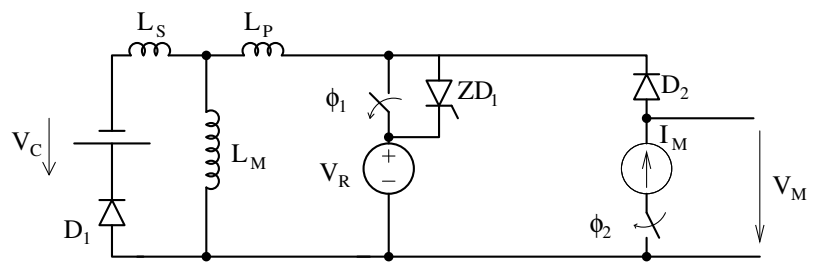

Fig. 3. Circuit model for cell voltage measurement operation.

Fig. 3 shows an equivalent circuit model for the cell voltage measurement operation. The measurement of cell voltage is complicated by the presence of the diode D 1 in the secondary side of the transformer and the circuit configuration for flyback operation. The diode D 1 introduces a current dependent forward drop voltage that is sensitive to temperature. The presence of the diode D2 in the cell interface unit, provides an identical diode which should be at the same temperature as D1. However, their voltage drop will only be equal if they are carrying the same current. Thus during the measurement part of the cell monitoring operation, a bias current sink circuit draws a fixed current through the transformer primary and diode D 2 to allow for cancelling of the diode D 1 voltage drop.

The measurement operation proceeds by storing energy in the transformer during a first phase, and performing the voltage measurement during a second fly-back phase. There is a short transient phase in-between during which the leakage inductances redistribute currents. Fig. 4 shows the equivalent circuits during this sequence of operations.

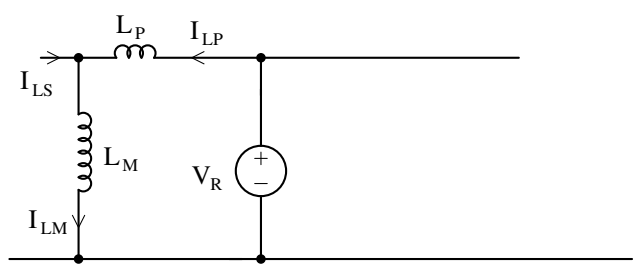

(a) First Phase

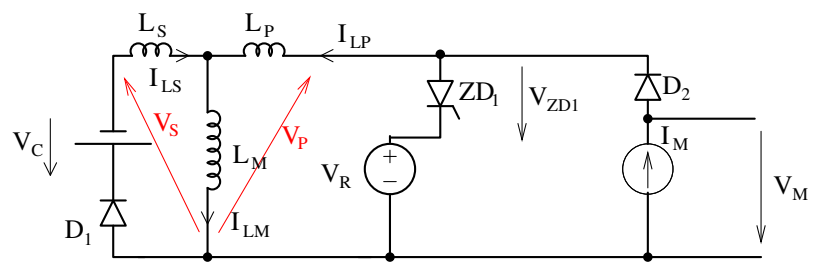

(b) Transient Phase

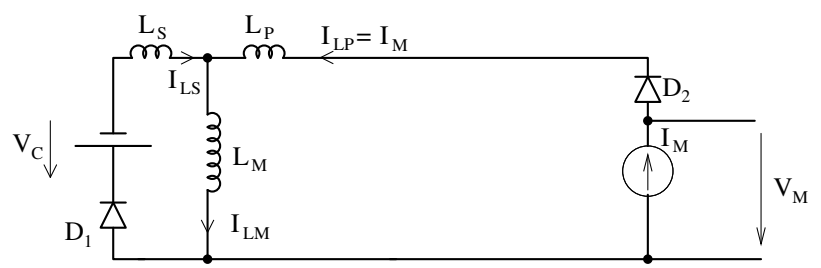

(c) Second Phase

Fig. 4. Sequence of equivalent circuits during voltage measurement operation.

During the first phase of $T_{1}$ seconds, Fig. 4(a), the voltage source $V_{R}$ is switched across the transformer primary and the magnetizing and primary leakage inductor current rises to $I_{0}$ with

$$
I_{0}=\frac{T_{1} V_{R}}{L_{M}+L_{L p}} .
$$

The voltage source $V_{R}$ is switched out of the circuit and the circuit starts with the initial conditions:

$$
I_{L s}(0)=0, \quad I_{L M}(0)=I_{0}, \quad I_{L p}(0)=I_{0}
$$

As phase one ends, the circuit enters a transient phase as per Fig. 4(b). The voltage across the secondary of the transformer 
is $V_{S}=-V_{C}-V_{F D 1}$ and the voltage across the primary of the transformer is $V_{P}=-V_{Z D 1}+V_{R}$, with $V_{F D 1}$ being the average forward drop voltage of diode D1 and $V_{Z D 1}$ being the zener diode breakdown voltage.

The transient phase ends with the leakage inductance current $I_{L P}$ being equal to the measurement current $I_{M}$. The second phase then proceeds with the leakage inductance current $I_{L S}$ decaying from approximately $I_{0}-I_{M}$ to zero, and this current flowing through the cell.

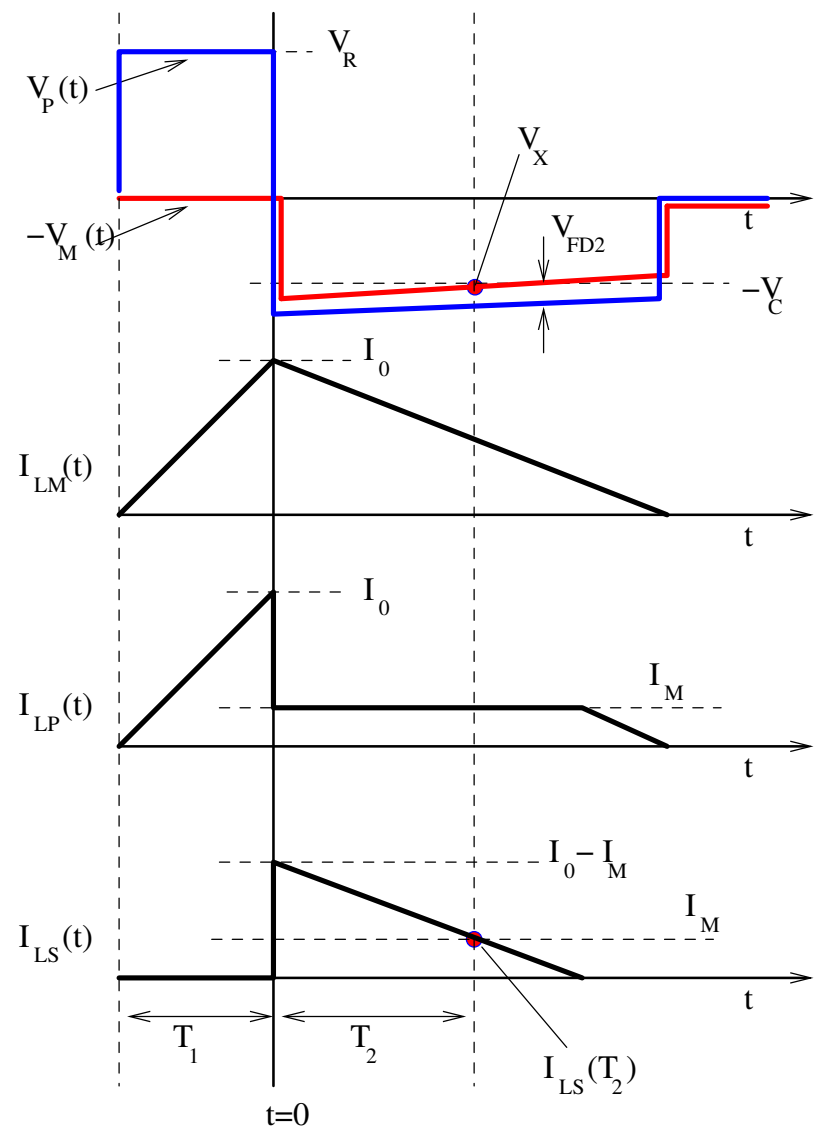

Fig. 5. Ideal waveforms during voltage measurements.

A good quantitative approximation to the operation of the measurement can be achieved by assuming the leakage inductances $L_{S}$ and $L_{P}$ are sufficiently small that they can be ignored (and thus the transient phase is sufficiently short, as verified in section III-A). Fig. 5 shows the voltage and current waveforms in this case. The current $I_{0}$ is approximated as:

$$
I_{0} \approx \frac{T_{1} V_{R}}{L_{M}} \text {. }
$$

Phase 2 begins with the primary current $I_{L P}=I_{M}$ and the secondary current starting at $I_{0}-I_{M}$ due to the action of the bias current sink. The secondary voltage is $-V_{C}-$ $V_{F D 1}\left(I_{L S}(t)\right)$ and this phase proceeds for a time $T_{2}$ at which time the measurement voltage $V_{M}(t)$ is sampled (denoted $\left.V_{X}=V_{M}\left(T_{2}\right)\right)$ to give:

$$
V_{X}=V_{C}+V_{F D 1}\left(I_{L S}\left(T_{2}\right)\right)-V_{F D 2}\left(I_{M}\right)
$$

where $V_{F D 1}\left(I_{L S}\left(T_{2}\right)\right)$ and $V_{F D 2}\left(I_{M}\right)$ are the diode forward drop voltages of diodes D1 and D2, which are functions of their forward current and temperature. If the time $T_{2}$ is chosen such that $I_{L S}\left(T_{2}\right)=I_{M}$ and both diodes are at the same temperature, then the measurement voltage $V_{X}=V_{C}$ and the cell voltage is measured without error.

However the ideal sampling time value is a function of the cell voltage and thus the strategy employed in this paper is to choose the time $T_{2}$ such that the correct cell voltage is measured for the nominal cell voltage $V_{C n o m}$ and account for the measurement error when the cell voltage differs from the nominal value.

The actual current $I_{L S}\left(T_{2}\right)$ can be calculated as:

$$
I_{L S}\left(T_{2}\right)=I_{0}-I_{M}-\frac{1}{L_{M}} \int_{0}^{T_{2}} V_{C}+V_{F D 1}\left(I_{L S}(t)\right) d t
$$

Taking $I_{L S}(0)=I_{0}-I_{M}$, then applying the trapezoidal integration approximation

$I_{L S}\left(T_{2}\right) \approx I_{0}-I_{M}-\frac{T_{2}}{L_{M}}\left[V_{C}+\frac{V_{F D 1}\left(I_{0}-I_{M}\right)+V_{F D 1}\left(I_{L S}\left(T_{2}\right)\right)}{2}\right]$

and the value of $T_{2}$ is chosen such that $I_{L S}\left(T_{2}\right)=I_{M}$ when $V_{C}=V_{C n o m}$. Hence $T_{2}$ is chosen as

$$
T_{2}=\frac{L_{M}\left(I_{0}-2 I_{M}\right)}{V_{C n o m}+\frac{V_{F D 1}\left(I_{0}-I_{M}\right)+V_{F D 1}\left(I_{M}\right)}{2}} .
$$

Eliminating $L_{M}$ by using eqn 3 , and denoting $\frac{1}{2}\left(V_{F D 1}\left(I_{0}-\right.\right.$ $\left.\left.I_{M}\right)+V_{F D 1}\left(I_{M}\right)\right)=\overline{V_{F D x}}$ then

$$
T_{2}=T_{1} \frac{I_{0}-2 I_{M}}{I_{0}}\left[\frac{V_{R}}{V_{C n o m}+\overline{V_{F D x}}}\right]
$$

With the value of $T_{2}$ chosen for nominal cell voltage $V_{C n o m}$ and with $\overline{V_{F D x}}$ evaluated at the nominal ambient temperature, the actual measured voltage at cell voltage $V_{C}$ is then:

$$
V_{X}=V_{C}+V_{F D 1}\left(I_{L S}\left(T_{2}\right)\right)-V_{F D 2}\left(I_{M}\right)
$$

With the ideal diode equation

$$
V_{F D}(I)=\frac{k \theta_{T}}{q} \ln \frac{I}{I_{S}}
$$

where $k$ is Boltzmann constant, $\theta_{T}$ is the diode absolute temperature, $q$ is the charge on the electron and $I_{S}$ is the diode saturation current parameter, then with identical diodes:

$$
V_{X}=V_{C}+\frac{k \theta_{T}}{q} \ln \frac{I_{L S}\left(T_{2}\right)}{I_{M}}
$$

and approximating

$$
I_{L S}\left(T_{2}\right) \approx I_{0}-I_{M}-\frac{T_{2}}{L_{M}}\left[V_{C}+\overline{V_{F D y}}\right]
$$

and with $\frac{1}{2}\left(V_{F D 1}\left(I_{0}-I_{M}\right)+V_{F D 1}\left(I_{L S}\left(T_{2}\right)\right)\right)=\overline{V_{F D y}}$, eliminating $L_{M}$ by using eqn 3 and using eqn 8 ,

$$
V_{X}=V_{C}+\frac{k \theta_{T}}{q} \ln \left(1+\frac{\left(I_{0}-2 I_{M}\right)}{I_{M}}\left[\frac{\Delta V_{C}+\overline{\Delta V_{D}}}{V_{C n o m}+\overline{V_{F D x}}}\right]\right)_{13)}
$$

where $\Delta V_{C}=V_{C n o m}-V_{C}$ and $\overline{\Delta V_{D}}=\overline{V_{F D x}}-\overline{V_{F D y}}$. The right hand term in eqn 13 is an error between the measured voltage and the actual cell voltage. This error is zero at the nominal cell voltage $V_{C n o m}$ under which condition both $\Delta V_{C}$ and $\overline{\Delta V_{D}}$ are zero. 
Note that selecting the measurement current $I_{M}$ equal to $I_{0} / 2$ would result in the error term being zero, but would also require the value of $T_{2}$ to be zero from eqn 8 , thus requiring sampling at the end of the transient phase, where some ringing is inevitably expected. In practice a value of $I_{M}$ of the order $I_{0} / 4$ is used to allow sufficient time for any ringing to settle. However, this leaves the error term non-zero when the cell voltage differs from the nominal value. The error term in eqn. 13 can be numerically evaluated and is plotted in Fig. 6 as a function of the cell voltage and at a range of different temperatures using a nominal voltage of $3.4 \mathrm{~V}$. The error varies from $-12 \mathrm{mV}$ to $+15 \mathrm{mV}$, but in a reasonably linear manner. Correcting the error with a gain and offset correction using a two point calibration at $25 \mathrm{deg} \mathrm{C}$, results in an error below $\pm 5 \mathrm{mV}$ over voltage and temperature in the figure. Gain and offset correction can also account for other systematic linear errors in the system such as leakage inductance, gains and offsets in the ADC and analogue front end electronics including the bias current sink. Measurements on a prototype design in section III confirm that an error level below $\pm 10 \mathrm{mV}$ is feasible in practice. A small amount of energy is transferred to the cell during this measurement process, but with a voltage monitoring rate of 16 samples per second, an average charge current of about $4 \mathrm{uA}$ is supplied.

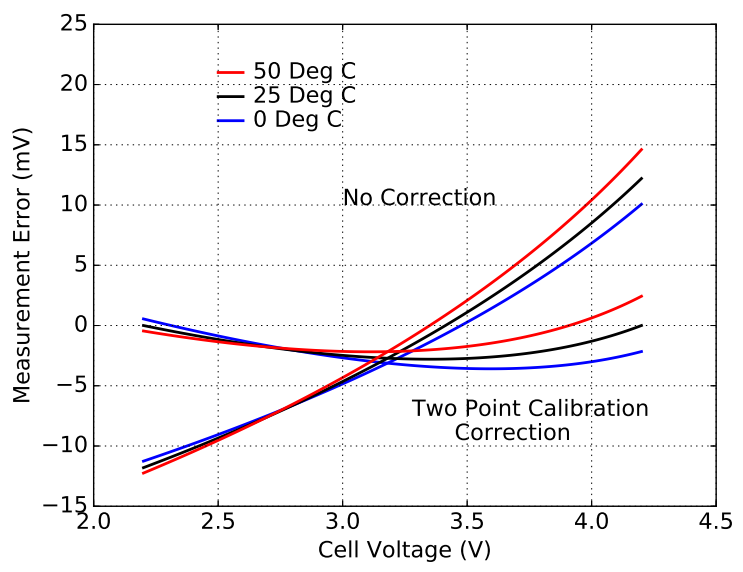

Fig. 6. Theoretical accuracy with and without two point calibration.

\section{B. Cell Current Balancing}

The requirement for cell balancing in addressed in this design by transferring energy into individual cells (i.e. charging them)[8]. The maximum power transfer requirement is determined by the amount of cell mismatch expected and the time available to perform the balancing operation[1].

With the proposed cell interface unit the maximum power transfer is essentially determined by the transformer element. The power transfer during balancing is performed with the flyback method and the discontinuous conduction mode is the simplest to implement and control with multiple cells being simultaneously balanced. Energy is stored in the transformer core from the auxiliary supply during a first phase, and released to the cell in a second phase. During balancing this is repeated constantly, to effect the desired power transfer level.
However not all this power is transferred to the cell. A significant portion is dissipated in the diode D 1 and there are also resistive losses in the transformer winding's. For example, with a diode drop of $0.7 \mathrm{~V}$ and nominal cell voltage of $3.3 \mathrm{~V}$, then the efficiency cannot exceed $82.5 \%$. In this paper, the requirements for the transformer are primarily driven by the requirement for accurate voltage monitoring and balancing efficiency is not the primary consideration[1].

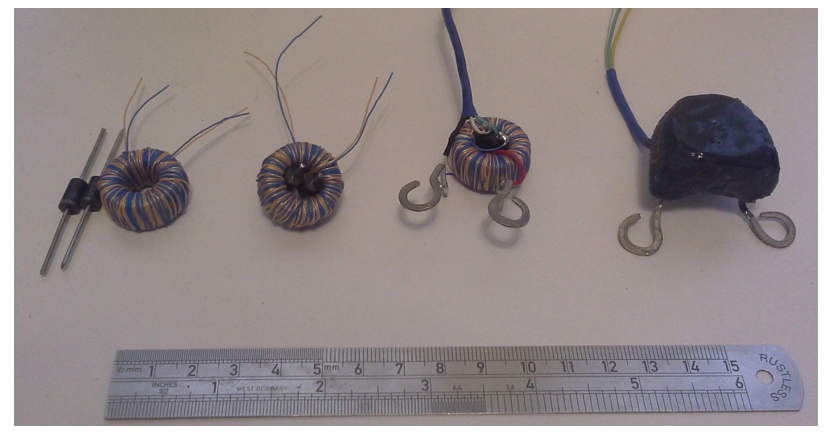

Fig. 7. Construction of Prototype Cell Interface Units.

\section{PRototype Design AND VerificAtion}

\section{A. Cell Interface Unit}

A set of 16 cell interface units are constructed to verify the operation of the proposed techniques and the construction sequence is shown in Fig. 7 with the components used and measured parameters listed in table I. Two jointly wound winding's of insulated 30 AWG wire are wound on a ferrite powder core and the two matched diodes (DO-201 packages) fit within the core in close thermal contact. The connections are wired up and the whole unit is molded in an epoxy compound for direct connection to the cell terminals. The

TABLE I

Prototy pe Cell Interface Unit Measured Parameters.

\begin{tabular}{|c|c|}
\hline Magnetic Core & T80-26B ferrite powder \\
Dimensions & $20.5 \mathrm{~mm} \mathrm{OD}, 12 \mathrm{~mm} \mathrm{ID}$ \\
height & $9.8 \mathrm{~mm}$ \\
$\mu_{R}$ & 75 \\
Number Turns & $65 \mathrm{~T} 30 \mathrm{AWG}$ wire \\
Magnetizing Inductance & $290 . \mu \mathrm{H}$ \\
Leakage Inductance & $2.75 \mu \mathrm{H}$ \\
DC resistance & $0.65 \Omega$ \\
& per winding \\
Diodes & $2 \times$ IN5404 \\
\hline
\end{tabular}

core material is chosen for its low temperature variation and operated at low current to maintain linear operation during the voltage monitoring operation. Once assembled and and wired up with the battery management system electronics, a one time calibration of the monitor current using the sense resistor RS of Fig. 2, is done to set the current level $I_{0}$ to $100 \mathrm{~mA}$. The bias current sink level $I_{M}$ is set as $25 \mathrm{~mA}$ for prototype system. Fig 8 shows the measured primary current and measurement voltage waveforms for the prototype system with a cell voltage of $3.2 \mathrm{~V}$ and shows the transient phase lasting for less than $1 \mathrm{uS}$, allowing for accurate voltage measurements. 


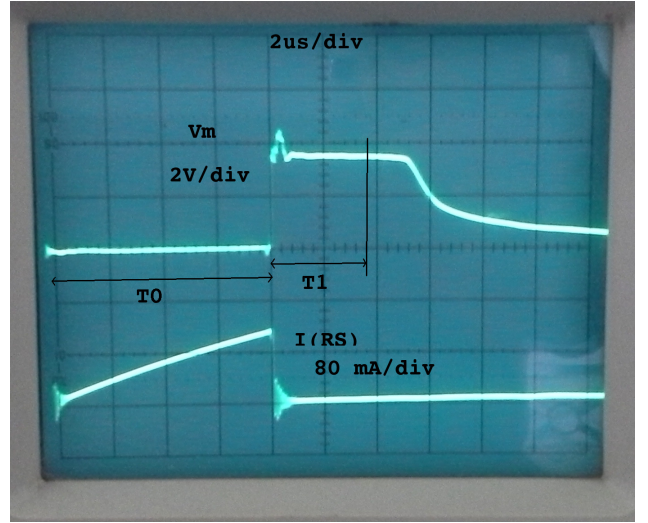

Fig. 8. Transformer primary current $I(R S)$ and measurement voltage $V m$ waveforms for the prototype system.

To evaluate the accuracy of the voltage measurements, the 16 prototype cell interface units and prototype system were calibrated at two points $(2.2 \mathrm{~V}$ and $4.2 \mathrm{~V})$ at $25 \mathrm{deg} \mathrm{C}$. The BMS system reported voltage was then measured over the input voltage range of $2.2 \mathrm{~V}$ to $4.2 \mathrm{~V}$ and with the cell interface units at 0,25 and $50 \mathrm{deg}$ C. Fig. 9 shows the resulting data with a total measurement error within $\pm 10 \mathrm{mV}$ over the temperature and voltage range and even better over the LiFePO4 operation window of $2.8 \mathrm{~V}$ to $3.6 \mathrm{~V}$, thus confirming the suitability of the system for individual cell monitoring. Note that for a different cell chemistry, the design could be centered around a higher nominal voltage.

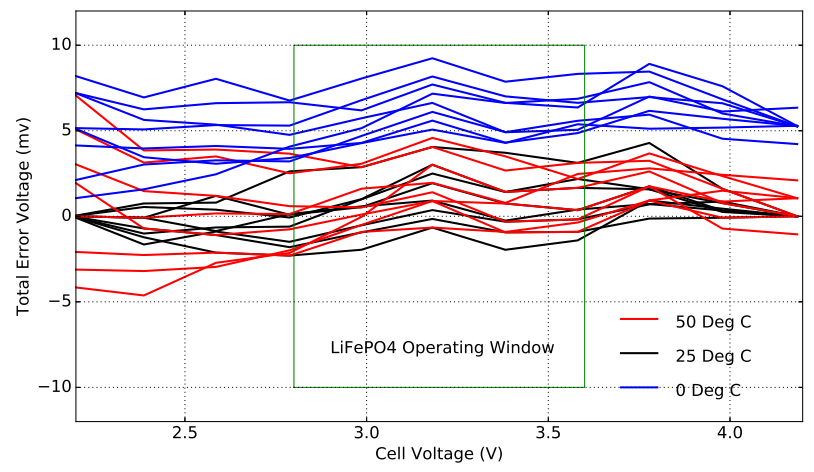

Fig. 9. Voltage Measurement accuracy for 8 units over voltage and temperature (0 deg $\mathrm{C}$ to $50 \mathrm{deg} \mathrm{C})$.

The balancing efficiency of the cell interface unit was measured with a $12 \mathrm{~V}$ auxiliary supply supplying a charge current to a $3.35 \mathrm{~V}$ reference test load. The resulting efficiency in terms of supplied power to the cell divided by the power drawn from the auxiliary supply is shown in Fig. 10. The measured average cell current was readily variable from $50 \mathrm{~mA}$ to $500 \mathrm{~mA}$ and with efficiency dropping from over $60 \%$ at low currents towards $40 \%$ at $500 \mathrm{~mA}$. The efficiency was limited by the forward drop voltage of the silicon diode D 1 and the resistive losses of the transformer winding's. The range of currents supported is sufficient for large (up to 100Ah) battery pack in electric vehicle applications where cells tend to be well matched and regularly balanced[1].

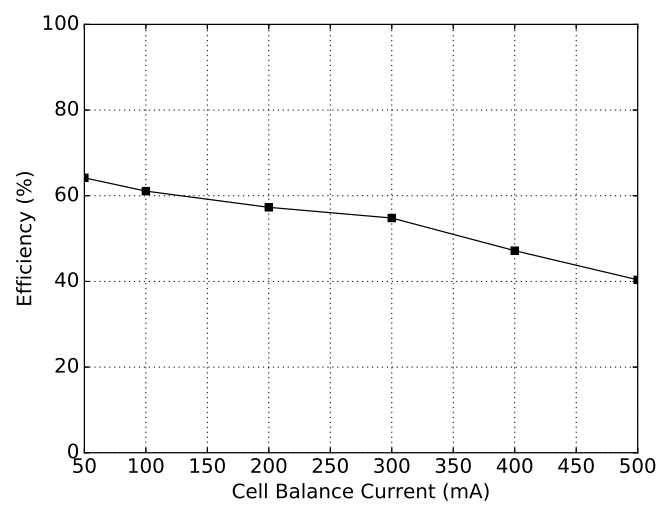

Fig. 10. Measured Efficiency of balancing efficiency versus cell balance current.

\section{B. Battery Module}

To demonstrate the usage of the cell interface unit, a prototype battery module is constructed. The battery module uses a stack of 16 series connected 2 parallel 20 Ah lithium iron phosphate (LiFePO4) cells. Fig. 11 shows a photo of the prototype $2 \mathrm{kWh}$ battery module consisting of $32 \mathrm{LiFePO} 4$ 20 Ah cells, connected in a 16s 2 p configuration. Each parallel cell pair has a single cell interface unit mounted directly on its terminals with its wiring being brought outside the module enclosure to a BMS circuit board outside. A key advantage of the architecture is that the wiring from each cell interface unit coming outside the enclosure is completely galvanically isolated from the cell voltages. This provides a significant safety advantage and allows the BMS circuit board to be modified or replaced without high voltage precautions. For example, in an automotive application, a faulty BMS circuit board could be replaced by a technician without the need to open the battery module and expose high voltages. The BMS circuit is accessed and controlled through a CAN bus and is supplied with $12 \mathrm{~V}$ auxiliary supply. Scaling is supported by adding additional modules in series and connecting the $12 \mathrm{~V}$ auxiliary supply to each in parallel and adding them to the CAN bus.

The functional operation of the developed BMS with the prototype module is shown in Fig. 12. In this operation the module was charged from $75 \%$ state of charge (SoC) to $100 \%$ SoC with a constant current of $2.5 \mathrm{~A}$ until any cell reached the terminal voltage of $3.45 \mathrm{~V}$. At that point, the constant current charger was disconnected and a balancing operation was started. Each cell with a voltage less than $3.45 \mathrm{~V}$ was simultaneously charged with a $250 \mathrm{~mA}$ current until it reached the $3.45 \mathrm{~V}$ level. This operation required about 40 minutes to complete and illustrates the correct functioning of the prototype system, including its ability to monitor the cell voltages accurately as well as perform active balancing. 
TABLE II

COMPARISON WITH OTHER BMS'S FROM THE LITERATURE. NOTE: COMPONENTS ARE; T TRANSFORMER, M MOSFET (AND DRIVER), D DIODE, Z ZENER DIODE, R RESISTOR AND C CAPACITOR. WIRING IS: HV BMS WIRING IS AT THE BATTERY STACK POTENTIAL, LV BMS WIRING IS AT THE LOW VOLTAGE ISOLATED SUPPLY POTENTIAL.

\begin{tabular}{|c|c|c|c|c|c|c|c|c|}
\hline Ref: & Topology & $\begin{array}{l}\text { Isolation } \\
\text { per Cell }\end{array}$ & $\begin{array}{c}\text { Per Cell } \\
\text { Components }\end{array}$ & $\begin{array}{l}\text { Balance } \\
\text { Current }\end{array}$ & $\begin{array}{l}\text { Balancing } \\
\text { Efficiency }\end{array}$ & $\begin{array}{c}\text { Voltage } \\
\text { Monitoring }\end{array}$ & $\begin{array}{l}\text { Voltage } \\
\text { Accuracy }\end{array}$ & $\begin{array}{l}\text { Module } \\
\text { Wiring }\end{array}$ \\
\hline$[8]$ & $\begin{array}{l}\text { Multi-Transformer } \\
\text { Parallel Balance }\end{array}$ & $\begin{array}{l}\text { Non Isolated } \\
\text { (via ADC) }\end{array}$ & 1T 1D 2M & $\overline{2 \mathrm{~A}}$ & $85 \%$ & $\begin{array}{l}\text { External } \\
\text { ADC }\end{array}$ & & $\begin{array}{c}\mathrm{HV} \\
\text { (for ADC) }\end{array}$ \\
\hline [10] & $\begin{array}{l}\text { Switched Capacitor } \\
\text { Parallel Balance }\end{array}$ & Non Isolated & $1 \mathrm{C} 2 \mathrm{M}$ & $\approx 0.5 \mathrm{~A}$ & High & None & & $\mathrm{HV}$ \\
\hline [11] & $\begin{array}{l}\text { Switch-Matrix } \\
\text { Serial Balance }\end{array}$ & Non Isolated & $2 \mathrm{M}$ & $0.2 \mathrm{~A}$ & $80.4 \%$ & $\begin{array}{l}\text { External } \\
\text { ADC }\end{array}$ & & $\mathrm{HV}$ \\
\hline [6] & $\begin{array}{c}\text { Switch-Matrix } \\
\text { Modular Balance }\end{array}$ & Non Isolated & $\begin{array}{c}2 \mathrm{M} \\
\frac{1}{12} \times \text { LTC6802 }\end{array}$ & $2 \mathrm{~A}$ & $82 \%$ & LTC6802 & $\pm 8 \mathrm{mV}$ & $\mathrm{HV}$ \\
\hline [12] & $\begin{array}{c}\text { Resistor } \\
\text { Passive Balance }\end{array}$ & Non Isolated & $\begin{array}{c}\frac{1}{18} \times \text { LTC6813 } \\
1 \mathrm{R}\end{array}$ & $0.1 \mathrm{~A}$ & $0 \%$ & LTC6813 & $\pm 4.2 \mathrm{mV}$ & $\mathrm{HV}$ \\
\hline [9] & $\begin{array}{l}\text { Multi-Transformer } \\
\text { Monitor only }\end{array}$ & 1 Transformer & 1T 1M 1D & None & & Yes & $1 \mathrm{mV}$ & $\overline{L V}$ \\
\hline $\begin{array}{l}\text { This } \\
\text { Work }\end{array}$ & $\begin{array}{c}\text { Multi-Transformer } \\
\text { Monitor AND Balance }\end{array}$ & 1 Transformer & $1 \mathrm{~T} 2 \mathrm{D} 1 \mathrm{Z} 1 \mathrm{M}$ & $\begin{array}{r}50 \mathrm{~mA} \\
\text { to } 0.5 \mathrm{~A}\end{array}$ & $\begin{array}{l}64 \% \\
\text { to } 40 \%\end{array}$ & Yes & $\pm 10 \mathrm{mV}$ & LV \\
\hline
\end{tabular}

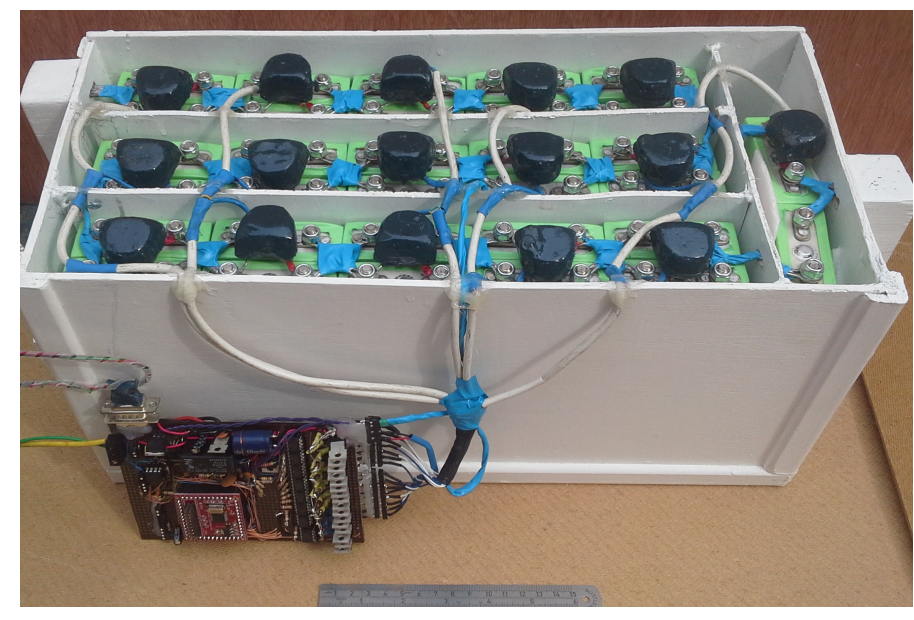

Fig. 11. $16 \mathrm{~s} 2 \mathrm{p} \times 20 \mathrm{Ah} \mathrm{LiFePO} 4$ cells $2 \mathrm{kWh}$ battery module with 16 cell interface units and proposed battery management system.

\section{CONCLUSIONS AND COMPARISON With OTHER ARCHITECTURES}

The proposed architecture is shown to effectively perform the two key per cell functions of voltage monitoring and cell balancing required for a complete BMS. These functions are achieved with an cell interface unit on the cell terminals that provides complete galvanic isolation for the BMS wiring within the battery module enclosure. Table II lists a range of different architectures from the literature under a number of important system headings. The active balancing schemes focus on the balancing and its efficiency and either do not consider the voltage monitoring function or require a separate monitoring system to be implemented. The passive balancing schemes perform both functions, but require wiring directly from the cell terminals to a balancing board making at least part of the board operate at the battery voltage, often requiring fuses per cell for safety, requiring isolation for the circuit board outputs and making assembly, repair or replacement of boards a difficult task, especially in high voltage systems like

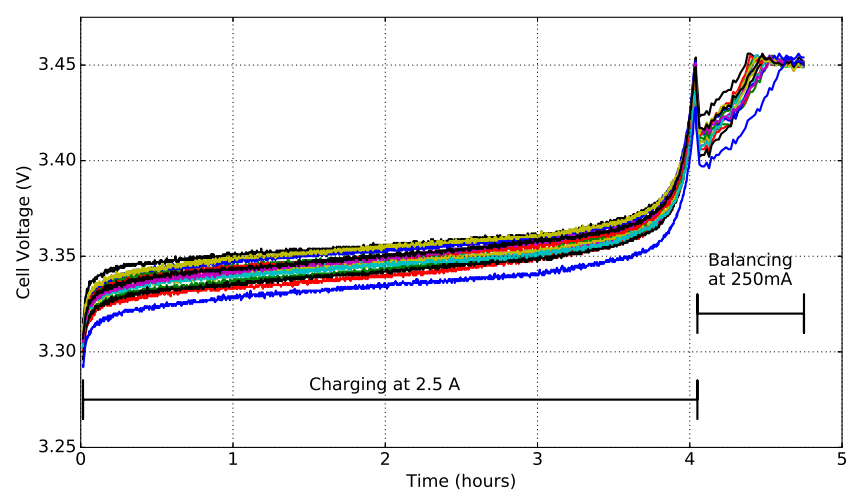

Fig. 12. Cell voltage for 16 parallel pairs of cells when charging from $75 \% \mathrm{SOC}$ until any cell reaches $3.45 \mathrm{~V}$ and then performing a module balancing operation to bring all cells to $3.45 \mathrm{~V}$.

electric vehicles. Only the proposed scheme achieved both the functions required, but providing full isolation with only low voltage wiring.

\section{REFERENCES}

[1] D. Andrea, "Battery Management Systems for Large Lithium Ion Battery Packs", Artech House, 2010, ISBN 1608071057, 9781608071050

[2] M. A. Hannan, M. M. Hoque, A. Hussain, Y. Yusof and P. J. Ker, "Stateof-the-Art and Energy Management System of Lithium-Ion Batteries in Electric Vehicle Applications: Issues and Recommendations," in IEEE Access, vol. 6, pp. 19362-19378, 2018.

[3] Y. Shang, C. Zhang, N. Cui and J. M. Guerrero, "A Cell-to-Cell Battery Equalizer With Zero-Current Switching and Zero-Voltage Gap Based on Quasi-Resonant LC Converter and Boost Converter," in IEEE Transactions on Power Electronics, vol. 30, no. 7, pp. 3731-3747, July 2015. doi: 10.1109/TPEL.2014.2345672

[4] Y. Chen, X. Liu, Y. Cui, J. Zou and S. Yang, "A MultiWinding Transformer Cell-to-Cell Active Equalization Method for Lithium-Ion Batteries With Reduced Number of Driving Circuits," in IEEE Transactions on Power Electronics, vol. 31, no. 7, pp. 4916-4929, July 2016.

[5] Y. Shang, C. Zhang, N. Cui and J. M. Guerrero, "A Cell-to-Cell Battery Equalizer With Zero-Current Switching and Zero-Voltage Gap Based on Quasi-Resonant LC Converter and Boost Converter," in IEEE Transactions on Power Electronics, vol. 30, no. 7, pp. 3731-3747, July 2015. 
[6] C. Kim, M. Kim and G. Moon, "A Modularized Charge Equalizer Using a Battery Monitoring IC for Series-Connected Li-Ion Battery Strings in Electric Vehicles," in IEEE Transactions on Power Electronics, vol. 28, no. 8, pp. 3779-3787, Aug. 2013. doi: 10.1109/TPEL.2012.2227810

[7] Y. Hsieh, T. Liang, S. O. Chen, W. Horng and Y. Chung, "A Novel High-Efficiency Compact-Size Low-Cost Balancing Method for SeriesConnected Battery Applications," in IEEE Transactions on Power Electronics, vol. 28, no. 12, pp. 5927-5939, Dec. 2013.

[8] C. Kim, Moon-Young Kim and G. Moon, "Individual cell equalizer using active-clamp flyback converter for li-ion battery strings in an electric vehicle," 2012 IEEE Vehicle Power and Propulsion Conference, Seoul, 2012, pp. 327-332.

[9] J. Williams and M. Thoren, "Developments in Battery Stack Voltage Measurement", Linear Technology Application Note 112 March 2007.

[10] Y. Ye, K. W. E. Cheng, Y. C. Fong, X. Xue and J. Lin, "Topology, Modeling, and Design of Switched-Capacitor-Based Cell Balancing Systems and Their Balancing Exploration," in IEEE Transactions on Power Electronics, vol. 32, no. 6, pp. 4444-4454, June 2017. doi: 10.1109/TPEL.2016.2584925

[11] K. Lee, S. Lee, Y. Choi and B. Kang, "Active Balancing of Li-Ion Battery Cells Using Transformer as Energy Carrier," in IEEE Transactions on Industrial Electronics, vol. 64, no. 2, pp. 1251-1257, Feb. 2017.

[12] Fraunhofer Institute for Integrated Systems and Device Technology IISB, "fox BMS",10-April-2020. [Online]. Available: https://foxbms.org/technical-specifications/ [Accessed: 10-April-2020]. 